\title{
Lean Approach in Knowledge Work
}

\author{
Hanna Kropsu-Vehkapera ${ }^{1}$ (D), Ville Isoherranen ${ }^{1,2}$ (D) \\ ${ }^{1}$ University of Oulu (Finland), ${ }^{2}$ Kerttu Saalasti Institute (KSI) (Finland) \\ hanna.kropsu-vehkapera@oulu.fi,ville.isoherranen@oulu.fi
}

Received: February 2018

Accepted: April 2018

\section{Abstract:}

Purpose: Knowledge work productivity is a key area of improvement for many organizations. Lean approach is a sustainable way to achieve operational excellence and can be applied in many areas. The purpose of this novel study is to examine the potential of using lean approach for improving knowledge work practices.

Design/methodology/approach: A systematic literature review has been carried out to study how lean approach is realized in knowledge work. The research is conceptual in nature and draws upon earlier research findings.

Findings: This study shows that lean studies' in knowledge work is an emerging research area. This study documents the methods and practices implemented in knowledge work to date, and presents a knowledge work continuum, which is an essential framework for effective lean approach deployment and to frame future research focus in knowledge work productivity.

Research limitations/implications: This study structures the concept of knowledge work and outlines a concrete concept derived from earlier literature. The study summarizes the literature on lean in knowledge work and highlights, which methods are used. More research is needed to understand how lean can be implemented in complex knowledge work environment and not only on the repetitive knowledge work. The limitations of this research are due to the limited availability of previous research.

Practical implications: To analyze the nature of knowledge work, we implicate the areas where lean methods especially apply to improving knowledge work productivity. When applying lean in knowledge work context the focus should be using the people better and improving information flow.

Originality/value: This study focuses on adapting lean methods into a knowledge work context and summarizes earlier research done in this field. The study discusses the potential to improve knowledge work productivity by implementing lean methods and presents a unique knowledge work continuum to frame previous research and give focus for future research.

Keywords: lean, knowledge work, knowledge work continuum, knowledge work productivity, operational excellence

\section{Introduction}

Given increasingly competitive workplace settings, organizations are seeking ways to improve their work methods. The importance and challenge of improving knowledge work productivity has long been discussed (Drucker, 1969; Drucker, 1999b; Holtshouse, 2010), especially since organizations tend to require knowledge more so than physical 
work (Newell, 2015). More complex production systems demand labor that is capable of handling, combining and creating new knowledge (Pyöriä, 2005).

The challenge of knowledge work productivity has increased (Drucker 1999a; Laihonen, Jääskeläinen, Lönnqvist \& Ruostela, 2012); this is further enhanced by slow economic growth, particularly in Europe. Many manufacturing jobs have moved to China and East Asia in the last decade, and these countries are highly cost competitive, putting more pressure on higher-cost ones to develop their operations. The pressure of cost savings has now moved towards knowledge work, and office workers now face the same challenges as factory workers did a decade ago: their work can be done at lower costs at foreign companies who pay lower wages. As such, knowledge work productivity and efficiency is a key improvement area for many companies. Operational excellence must be achieved not only in factories but also in office settings. Lean methods are a potential approach to solving this challenge (Stone, 2012), and the number of studies about implementing lean methods in different fields have recently increased (e.g. Hadid \& Afshin Mansouri, 2014; Gupta, Sharma \& Sunder, 2016). However, there is currently no standard method of applying lean values, principles and tools to the knowledge-based workforce, leaving many companies struggling to implement successful lean projects (Staats \& Upton, 2011). These projects often fail to deliver value to organizations' pursuits of productivity, operational excellence and competitive advantage.

To employ lean thinking and approaches, it is crucial to understand the context of their application. For instance, the heterogeneity of the workforce makes it difficult to treat all service activities alike (Hadid \& Afshin Mansouri, 2014) where knowledge work is only a part of the work. The diverse nature of knowledge work also affects lean implementation possibilities. As such, the key objective is to understand the different characteristics connected to the concept of knowledge work and how these characteristics affect lean implementation. The concept of knowledge work is often lightly touched upon in research articles when discussing the nature of today's work; instead, such research often focuses on managing knowledge work, not managing the knowledge as a resource, which is typically the focus of knowledge management discourse (Aarons, Linger \& Burstein, 2006). In this paper, we examine the definition of knowledge work and identify possible lean applications for improving knowledge work productivity.

This paper is organized as follows. The first section presents definitions of knowledge work and knowledge work productivity with research propositions $(\mathrm{Ps})$ that are consistent with the research aims. This is summarized and authors propose a new knowledge work continuum to understand the nature of knowledge work. The research approach section describes how this study was conducted. Then the findings on lean implementations in knowledge work was studied based on the analysis of secondary data. Finally, we conclude the implications and discuss how lean approaches improve knowledge work productivity.

\section{Knowledge Work and Productivity}

The value of knowledge has been widely recognized in what we know as "the information age". Societies' and companies" successes are linked to their use of relevant knowledge, thus making knowledge work critical in many organizations (e.g. Holsthouse, 2010). Although we frequently discuss "doing knowledge work", the definition of knowledge work is complex and vague in nature (e.g. Pyöriä, 2005); the fact that all work demands knowledge to some extent poses a challenge in defining knowledge work concretely (Iivari \& Linger, 1999). In this chapter, the definition of knowledge work is further examined.

\subsection{Knowledge Work Definitions}

Drucker (1969) was the first author to define knowledge work as it is perceived today. The key focus of his definition is that knowledge work's primary function is managing information. Iivari's and Linger's (1999) definition agrees with this and furthermore their knowledge work concept emphasizes a deep understanding the work's content and outputs where knowledge is as an essential ingredient. As such, Iivari's and Linger's (1999) definition is knowledge-centred. Later, Davenport (2005) and Pyöriä (2005) outlined a more process-oriented approach to knowledge work. In their definitions, the real substance of knowledge work lies in its processes, not its results. Knowledge processes and connections in said processes are also regarded invisible and often more dynamic in 
nature than manufacturing work (Staats, Brunner \& Upton, 2011). Design work is an example of such work. Table 1 summaries the key aspects of the much-used definitions of knowledge work and their key focuses.

\begin{tabular}{|l|l|}
\hline Key Focus of Knowledge Work Definition & \multicolumn{1}{c|}{ Authors } \\
\hline Primary task is managing information. & Drucker 1969 \\
\hline $\begin{array}{l}\text { The work is based on the handling of the knowledge. } \\
\text { Deep understanding of the work's content. } \\
\text { Knowledge is an important output ingredient. } \\
\text { Collaborative in nature. }\end{array}$ & Iivari \& Linger 1999 \\
\hline $\begin{array}{l}\text { Process-based viewpoint of handling knowledge. } \\
\text { Dynamic in nature. } \\
\begin{array}{l}\text { Knowledge processes and their connections are invisible. } \\
\text { Often contains design activities and exploration. }\end{array}\end{array}$ & Davenport 2005; Pyöriä 2005 \\
\hline
\end{tabular}

Table 1. Key knowledge work definitions

Based on the above the following proposition was developed:

\section{P1. In knowledge work, information handling and processing is a primary task and knowledge is the main output.}

Knowledge work is intangible in nature and sometimes defined as a service (Laihonen et al., 2012). Paton (2009) has assessed that knowledge work cannot automatically be associated to service work, made distinct from manual work, or descriptive of emerging work forms, although the term "knowledge work" is often used incorrectly in such contexts. As such, in many studies (e.g. Toussant \& Berry, 2013; Gupta et al., 2016), the terms "knowledge work" and "services" are used synonymously without defining the context of knowledge work, thereby creating an inaccurate impression of what knowledge work is. A typical example is referring to simple office work, e.g. call centre work, as knowledge work even though it is more congruent with the manufacturing process (Bain, Watson, Mulvey, Taylor, \& Gall, 2002).

\subsection{Knowledge Work Continuum}

To develop knowledge work practices, we must better understand the nature of knowledge work. The difficulty in defining the concept or structure of knowledge work in general indicates that the work is diverse rather than uniform; it includes tasks that are different in terms of breadth and variety (Holtshouse 2010; Margaryan, Milligan \& Littlejohn, 2011). This is also noted as a challenge in studies that seek ways to improve knowledge work performance (e.g. Laihonen et al. 2012; Waters \& Beruvides 2012).

The knowledge work process can be divided into different types of activities: finding, creating, packaging, distributing and applying knowledge (Davenport, 2005). These activities affect the nature of work and work management, whether it involves repeated activities or handling work without strict control or task descriptions. On the other hand, a person doing knowledge work will face a variety of activities where some tasks are more routine whereas others are more creative in nature (Iivari \& Linger 1999; Aarons et al., 2006; Ramirez \& Steudel, 2008); these tasks often vary in their intensity (Dahoiee, Afrazeh \& Hosseini, 2011) and require multitasking (May, 2005). Staats et al. (2011) clearly states that the descriptive characteristic of knowledge work is its lack of repetition, which posits a decent definition of knowledge work. In addition to work structure (formal vs. fluid, consistency of routines, etc.), personal judgement and expertise are other basic aspects of knowledge work that determine a worker's control over how an activity is done (Davenport, 2005; Ramirez \& Steudel, 2008).

When defining knowledge work, it is essential to recognize the role of knowledge itself in the working process. How knowledge is used in work must be understood (Paton, 2009). There is a large difference between someone applying information (e.g. guiding customer in a call centre) or creatively using information for example in developing new products or defining strategy. Knowledge is a primary ingredient in the latter case, but a secondary production factor in the former (Pyöriä, 2005). Davenport (2005) lists many jobs, such as sales, computer 
programming, accounting, medicine and engineering, in which the primary objective is to apply existing knowledge rather than give rise to innovation.

The types of ideas handled in core activities also differentiate various knowledge work (Davenport, 2005): is the focus on developing radically new innovations, incremental changes or minor improvements? Such ideas can be clearly tied to different knowledge process activities (Margaryan et al., 2011) that can describe the complexity of the work involved. May (2005) defines knowledge work to be dynamic and complex, requiring strategic thinking and deeper problem solving where the capability processing information and ability handling the abstract sets of information (as opposed to simple transaction-based information) is key. Paton (2009) also states that one definitive criterion for knowledge workers should be their ability to add value to the organization.

Collaboration in knowledge work entails the work to be divided between groups or individuals. Very often demanding knowledge work is connected to individual expertise. However, knowledge intensive organizations to succeed in demanding work requires high organizational knowledge, which requires strong experts who can work together in collaborative ways (e.g. Iivari \& Linger, 1999; Holsthouse, 2010). Highly knowledge-intensive work may also require greater mobility (e.g. the ability to work in networks) and greater problem-solving skills (Davenport, 2005).

Based on the above the following proposition is developed:

P2. Knowledge work is multidimensional in nature. Within each dimension, there is wide variation in the essence of knowledge, level of working routines and standards, and persons own role in work.

Margaryan et al. (2011) state that one reason why knowledge work concepts and typologies are difficult to apply tend to be conceptual rather than empirical, as they are difficult to fit into real-world contexts. Additionally, the fact that knowledge work is a spectrum more so than a rigid concept is clear when examining different research about knowledge work. Some researchers (e.g. Ramirez \& Steudel, 2008; Dahoiee et al., 2011) have presented knowledge work as a continuum, where the basic assumption is that all jobs can be represented by this continuum. The challenge of these continuums is that they must include dimensions that are relevant to all types of work. For example, in Ramirez and Steudel (2008), one aspect of the continuum is physical effort required, but we challenge the relevancy of this factor in real knowledge work. Because of this, we have synthesized various aspects of the continuum based on earlier studies defining knowledge work (Drucker, 1969; Iivari \& Linger, 1999; Davenport, 2005; May, 2005; Pyöriä, 2005; Aarons et al., 2006; Ramirez \& Steudel, 2008; Paton, 2009; Dahoiee et al., 2011; Margaryan et al., 2011; Staats et al., 2011). By understanding knowledge work as a continuum comprised of different dimensions (Table 2), we can comprehend what type of aspects knowledge work may include.

The knowledge work continuum is typically understood to be able to represent all jobs (e.g. Ramirez \& Steudel, 2008; Dahoiee et al., 2011). Many authors' continuums suggest that all work is knowledge work when at least one of the factors in the continuum (those on the left side of the chart above) is more than 0 percent. These viewpoints clearly differ from traditional definitions of knowledge work (Drucker, 1969; Iivari \& Linger, 1999; Davenport, 2005; Pyöriä, 2005), where the key focus is the knowledge's role in the work, the main ingredient of the output, and the process of how knowledge is handled. Knowledge is required in all jobs in terms of how tasks need to be done and how certain tools or machines are used, but jobs entailing tasks and tools are not knowledge work by default.

\begin{tabular}{|l|c|c|}
\hline \multirow{2}{*}{\multicolumn{1}{c|}{ Dimension }} & \multicolumn{2}{c|}{ Continuum } \\
\cline { 2 - 3 } Level of routines (process orientation) & Office work & Innowledge work \\
\hline Formal methods & Systematic & Non-Standard \\
\hline Complexity of task & Standard & High \\
\hline Use of knowledge & Low & Create \\
\hline Knowledge as output ingredient & Apply \\
\hline
\end{tabular}




\begin{tabular}{|l|c|c|}
\hline \multirow{2}{*}{\multicolumn{1}{c|}{ Dimension }} & \multicolumn{2}{c|}{ Continuum } \\
\cline { 2 - 3 } & Office work & Knowledge work \\
\hline Type of knowledge & Facts, techniques, visions & High \\
\hline Personal expertise and judgement & Low & High \\
\hline Role of collaboration/collaborative thinking & Low & \\
\hline
\end{tabular}

Table 2. The knowledge work continuum - the eight dimensions

Our intention is not to state that all work is knowledge work, but rather underscore the heterogeneity of knowledge work. As a rough simplification, work profiles in knowledge work is presented in Figure 1, where the vertical axis describes the role of knowledge used in work and the horizontal axis the diversity of methods used. The role of knowledge is a combination of the dimensions of Use of knowledge, Knowledge as output ingredient and Type of knowledge (the dimensions are presented in Table 2). Methods is a combination of the dimensions of Level of routines, Formal methods, Complexity of task, Personal expertise and judgement and Role of collaboration.

Based on the above the following proposition is developed:

P3. The knowledge work continuum condenses the different aspects of knowledge work and provides a framework to understand the nature of knowledge work comprehensively. It proposes a classification where more routine and low complex work should handle as an office work and to more complex, innovative and knowledge output oriented work as knowledge work.

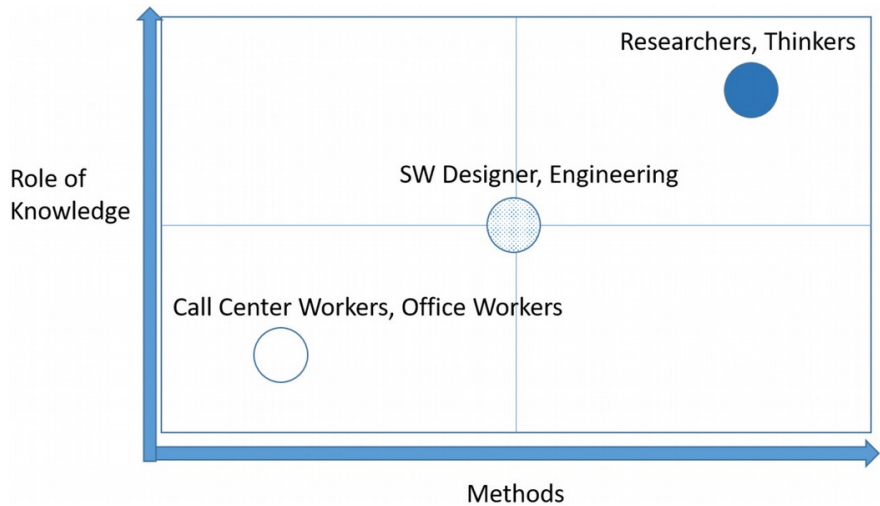

Figure 1. Examples of work profiles in knowledge work

\subsection{Challenges in Knowledge Work Productivity}

Discussions about productivity challenges in knowledge work have long been ongoing (Drucker, 1969; Drucker, 1999b; Holtshouse, 2010). Productivity is typically measured as output divided by input. In a knowledge work context, many relevant factors are intangible and qualitative in nature (Laihonen et al., 2012); the processes that transform inputs to outputs are often unstructured and are based on individual's knowledge and ability to apply learned experiences (Antikainen \& Lönnqvist, 2006), outputs are not standardized or even clearly determined, and the quality of worker output cannot be ignored (Davenport, 2005). The difficulty in defining knowledge work makes it more difficult to define productivity inputs, and the factors that can influence quantity and/or quality of output are thus challenging to analyze (Davenport, 2005). In knowledge work, evaluating performance in, e.g. creativity and problem solving, is also difficult but can tie into tangible measures, such as working hours (Davenport, 2005). Paying attention to these challenges, Laihonen et al. (2012) findings that surprisingly little research had been done about measuring productivity in knowledge work, is not so big surprise at all.

Drucker (1999b) defined six factors to determine knowledge worker productivity: the task at hand, self-management and autonomy, continuous innovation, continuous learning, quality of output (which is at least important than quantity), and the worker being handled as an asset instead of a cost. In contrast, Antikainen and Lönnqvist (2006) approach knowledge work productivity drivers via a traditional input-process-output model. 
Davenport (2005) states that viewing knowledge work as a process can be an effective way of improving performance. The most common forms of intervention are participatory, incremental and continuous, e.g. much like in Lean Six Sigma. This approach requires work structuring and task definition - what is the focus of work and what is the required quality level. In their study, Davenport, Järvenpää and Beers (1996) found that the methods applied to developing knowledge creation versus knowledge application process can vary and that these types of intervention methods, were somewhat easier to apply knowledge application process than on than knowledge creation process. When a task is defined, Drucker (1999b) states that knowledge workers themselves tackle productivity challenges as part of their jobs. Such behavior points to self-management, continuous innovation and learning. The dimensions of knowledge work productivity are summarized in Table 3 below.

Based on the above the following proposition is developed:

P4. Knowledge work challenges the traditional productivity definitions. Many aspects of the knowledge work are intangible and thus difficult to measure. However, making knowledge work visible and defining the work makes possible to manage knowledge work. productivity.

\section{Dimensions of Knowledge} Work Productivity

\begin{tabular}{|c|c|c|}
\hline $\begin{array}{l}\text { Task } \\
\text { Role of worker } \\
\text { Output } \\
\text { Management }\end{array}$ & $\begin{array}{l}\text { Assessing what the task is } \\
\text { Self-management and autonomy, continuing innovation, } \\
\text { continuous learning } \\
\text { Quality of output } \\
\text { Knowledge worker is an asset }\end{array}$ & Drucker, 1999b \\
\hline $\begin{array}{l}\text { Quantity } \\
\text { Costs and/or profitability } \\
\text { Timeliness } \\
\text { Autonomy } \\
\text { Efficiency } \\
\text { Quality } \\
\text { Effectiveness } \\
\text { Customer satisfaction } \\
\text { Innovation/creativity } \\
\text { Project success } \\
\text { Responsibility/ importance of work } \\
\text { Knowledge worker's perception of } \\
\text { productivity } \\
\text { Absenteeism }\end{array}$ & $\begin{array}{l}\text { Accounting for outputs and outcomes } \\
\text { Accounting for profitability, costs, etc. } \\
\text { Meeting deadlines, overtime needed, etc. } \\
\text { Independence and how many things can be done at once } \\
\text { Doing things right; meeting the task's standards } \\
\text { Level of the quality of the work } \\
\text { Doing the right things and important tasks } \\
\text { Product creates value for the customer } \\
\text { Ability to create and improve productivity } \\
\text { Overall results of the work; considers decision-making, team } \\
\text { interaction, communication, documentation, etc. } \\
\text { The importance of performing well at critical times } \\
\text { Possible misinterpretation of other standard factors } \\
\text { Results of average productivity measures; performing well overall }\end{array}$ & $\begin{array}{l}\text { Ramirez \& } \\
\text { Nembhard, } 2004\end{array}$ \\
\hline $\begin{array}{l}\text { Inputs } \\
\quad \text { Organisational inputs }\end{array}$ & $\begin{array}{l}\text { Human capital; innovative potential; organisational standards, } \\
\text { practices and routines; information systems; quality of } \\
\text { information; networks; time allocation; working environment; aim } \\
\text { Motivation; job satisfaction; personal network; personal life affairs; } \\
\text { physical fitness } \\
\text { Organisation of work; division of tasks; organisation of decision- } \\
\text { making; clarity of job descriptions; teamwork; knowledge sharing; } \\
\text { delays and waiting; ability to affect own work } \\
\text { Innovation; quality; utilisation of innovation; time-efficiency; } \\
\text { fulfilment of customer's expectations }\end{array}$ & $\begin{array}{l}\text { Antikainen \& } \\
\text { Lönnqvist, } 2006\end{array}$ \\
\hline
\end{tabular}

Table 3. The dimensions of knowledge work productivity

\section{Research Approach}

In this study, we determine that a knowledge worker is a person whose work includes using knowledge intensively in his/her work, but the term is not necessarily a job title. The definition of knowledge work contains different dimensions as described in Table 2. In this study, we want to examine the work where knowledge is the heart of the 
work and the key output ingredient, as opposed to work where knowledge is only a secondary resource and is obtained instead of processed. We focus on studying knowledge work where employees work knowledgeably meaning they can differentiate between complex patterns of data and information and respond based on existing frameworks or personal experiences (Newell, 2015). We are interested in studying the applicability of lean methods, in the following circumstances:

- When the knowledge is used for creating customer value

- When the work entails problem solving and using knowledge to creating new things

- When the work is based on strong personal competence/expertise.

We are focusing only on the above circumstances and not interested in studying general lean services that are not indicated to specific types of work or do not focus on the knowledge process. A typical flaw in many lean service studies is the assumption that all service work is knowledge work, even work that is repetitive and simple in nature, although such work may fall into the left side of the knowledge work continuum where the lean implementation handles "service production flow" (e.g. patients) rather than information itself.

Our purpose is to examine the potential to use lean applications for improving knowledge work practices. The research is conceptual in nature and makes use of earlier research findings (see Figure 2 for a research process illustration). A literature review was conducted to define knowledge work based on theoretical studies, we can conclude that knowledge work is a continuum.

On the next phase, we study lean in knowledge work. We briefly touch upon basic lean philosophies and methods. After that, we summarize and discuss the research done on implementing lean practices in knowledge work and conclude which applications and methods could be especially helpful when implementing lean methods in knowledge work. Lean implementations in knowledge work were studied using a literature review. The review was done on the Scopus database and entailed searching for joint keywords "lean" and "knowledge work" in titles, abstracts or keyword fields. No other criteria were set. The search yielded 24 results. Due the low number of original publications, other searches with the same search terms were made in different databases (Web of Science, Ebsco and ProQuest) to assess the search's validity. These additional searches did not return any additional articles for review. At first, the duplicate articles were removed. The next studies were eliminated from the review if they barely examined lean methods at all, as were articles in which knowledge work was only mentioned as a generic term without a clear description of how lean principles applied to knowledge work settings, much like in Kobus \& Westner's (2015) literature review that justified further research in lean IT management. A total of eight papers were used for the review, and the results of this analysis are presented in chapter 4.2. This is followed by a "discussion and implications" section in which the study's implications and limitations are reviewed.

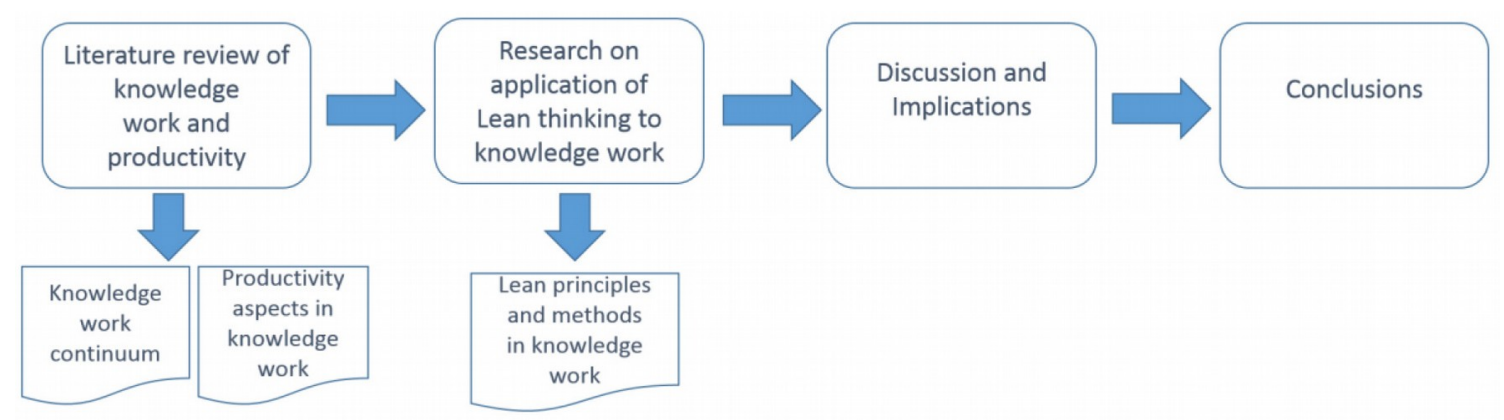

Figure 2. The research process 


\section{Lean in Knowledge Work}

\subsection{Lean Principles and Approaches to Knowledge Work}

The origins of lean philosophy have been widely disseminated by various scholars (e.g. Womack, Jones \& Roos, 1990; Hines, Holweg \& Rich, 2004; Liker, 2004), with Stone (2012) offering a review of relevant literature about the topic from the past four decades. Japanese management spawned this philosophy, the international Motor Vehicle Program and the management system known as the Toyota Production System (TPS) (Womack et al., 1990; Liker, 2004). Lean thinking combines years of practice and theory. The lean approach is based on the concept of customer value (Womack et al., 1990). "Lean thinking” is a set of principles that emphasize an organization's actions towards creating value for customers through continuous improvement (Hines et al., 2004). Lean thinking is a cultural change that focuses on utilizing people as efficiently as possible. Lean approaches are still developing, but the main concept of lean, providing value to the customer while reducing or removing activities that do not add value, remains as a base. This can be achieved though techniques called lean tools, which are counter-measures for avoiding or reducing non-valuable activities, things like waste in the processes.

Lean thinking as presented by Womack et al. (1990) can be condensed as follows: first, the customers' values must be defined and understood. Second, their value stream must be plotted to include links between the activities and processes that creates the products customers wish to buy; they must outline the inherent value that ultimately fulfil customers' requirements. Third, it is essential that there is flow between these linked activities so that there is process which produces the product or the service. Finally, there needs to be a pull in place; this pull refers to customers' driven demands that control and pull products or services in the value stream. All these essential lean elements must be combined with continuous improvement, which in turn would support the company's operations and lead it towards perfection, operational excellence.

In a knowledge work context, these lean thinking principles - which start and end with the customer - must be applied considering the special nature of knowledge work. The definition of value in knowledge work, which customers are ready to pay for, is often invisible and cannot be easily defined. The same problems exist in the concept of value streams and flow, which in knowledge work can be an iterative process consisting of loops. Oftentimes, value cannot be added without loops, and this is especially apparent in collaborative projects where each professional's work jointly on product or service, and their input increases the value by iterating the final output. This highlights the role of collaboration in knowledge work. A simple example of such work is this journal article, which was co-written digitally by multiple authors, improved upon, and reviewed by journal editors and other reviewers. This research paper is presented to the reader (customer) in the form of a journal article, but its value stream and flow, if mapped, would show many loops and iterations.

Finding 1. The Lean approach in knowledge work requires understanding the special nature of knowledge work; however, the universal lean principles can be applied.

The lean implementation approach depends on a company's existing level of organization and operational maturity. Maturity can be evaluated by the maturity model framework (Isoherranen, Niinikoski, Malinen, Jokinen, Kess \& Karkkainen, 2016). Although lean approaches have a long history in manufacturing environments, its applications in the field of knowledge work are still young; certain tools and methods are either still developing or do not yet exist. The lean deployment approach needs to be planned according to an organization's maturity, i.e. ability to adapt and learn. If change resistance is not considered, then the company's gap in knowledge about lean thinking will likely slow down or prevent the introduction of lean thinking. This problem has been recognized by various scholars (e.g. Staats \& Upton, 2011; Shah \& Ward, 2007). An important aspect of knowledge work productivity is to view knowledge workers as assets and as those who owning the means of production, since the improvement of knowledge work largely depends on their involvement in developmental work (Davenport et al., 1996; Drucker, 1999b).

Finding 2. To implement lean in knowledge work context highlight the role of workers. Lean implementation should thus start from philosophical level involving people rather than implementing specific tools that may also be impropriate to knowledge work context. 


\subsection{Previous Research on Lean in Knowledge work}

Earlier research about lean systems in knowledge work is very scarce (Table 4). The studies are qualitative in nature and follow either case study or action study research protocols, which both support discovering new phenomena. Finding research that focuses on information processing as a key to value creation is challenging, since the context of the knowledge work involved is rarely described well. Kruger (2014) and Toussaint and Berry (2013) do not define knowledge work themselves, but they maintain the viewpoint that work done in the healthcare field is intrinsically knowledge-related. However, May (2005), Staats and Upton (2011), Staats et al. (2011), McDermott and Venditti (2015) and Rachman and Ratnayake (2016) are among the first authors who clearly focused on lean implementation cases where the core is information processing.

\begin{tabular}{|c|l|l|l|}
\hline Year & \multicolumn{1}{|c|}{ Author } & \multicolumn{1}{|c|}{ Article Title } & \multicolumn{1}{c|}{ Field of Study } \\
\hline 2016 & $\begin{array}{l}\text { Rachman \& } \\
\text { Ratnayake }\end{array}$ & $\begin{array}{l}\text { Implementation of lean knowledge work in oil and gas industry - } \\
\text { A case study from a Risk-Based Inspection project }\end{array}$ & $\begin{array}{l}\text { Engineering service } \\
\text { (consultancy) }\end{array}$ \\
\hline 2015 & $\begin{array}{l}\text { McDermott \& } \\
\text { Venditti }\end{array}$ & $\begin{array}{l}\text { Implementing lean in knowledge work: Implications from a study } \\
\text { of the hospital discharge planning process }\end{array}$ & Healthcare \\
\hline 2015 & Power \& Conboy & $\begin{array}{l}\text { A Metric-Based Approach to Managing Architecture-Related } \\
\text { Impediments in Product Development Flow: An Industry Case } \\
\text { Study from Cisco }\end{array}$ & Product development \\
\hline 2013 & Truger & Lean implementation in the Gauteng public health sector & Healthcare \\
\hline 2011 & Staats \& Upton & Lean knowledge work & Healthcare \\
\hline 2011 & $\begin{array}{l}\text { Staats, Brunner \& } \\
\text { Upton }\end{array}$ & $\begin{array}{l}\text { Lean principles, learning, and knowledge work: Evidence from a } \\
\text { software services provider }\end{array}$ & $\begin{array}{l}\text { SW services/ } \\
\text { engineering } \\
\text { perspective }\end{array}$ \\
\hline 2005 & May & Lean thinking for knowledge work & General; philosophy \\
\hline
\end{tabular}

Table 4. Earlier research on lean approaches in knowledge work

Finding 3. Earlier research on lean approaches in knowledge work is scarce. There is intriguing interest to apply proven effective lean methods to tackle knowledge work productivity and development issues.

\subsection{Lean Principles and Methods in Knowledge Work}

Staats et al. (2011) and May (2005) discuss lean implementation in knowledge work on a more generic and philosophical level rather than applying specific tools and methods to a certain case. May (2005) sees that focusing on value, flow and continuous improvement are key lean principles that are also relevant in knowledge work. Power and Conboy (2015), Kruger (2014), Toussaint and Berry (2013) and both of Staats' (2011) studies also discuss lean implementation holistically and without focusing only on single lean principles or methods.

Although maintaining employee respect is a fundamental principle of lean theory, this factor is not seriously discussed in these papers. Toussaint and Berry (2013) are the ones clearly indicating people respect in their study. In other studies, people respect accompanies inclusive lean implementation methods, but is more so interpreted than explicitly indicated in any given case (Staats et al., 2011; McDermott \& Venditti, 2015; Power \& Conboy, 2015). Another lean principle, creating continuous learning/development culture, is in turn more practically handled. In the field of knowledge work, PDCA or PDSA (Plan-Do-Check/Study-Act), DMAIC (Define-Measure-Analyze-Improve-Control) and other hypothesis-driven methods of problem solving are applied to the practice of continuous improvement (May, 2005; Staats \& Upton, 2011; Toussaint \& Berry, 2013; Kruger, 2014).

Value stream mapping (VSM) and eliminating waste are the first issues typically applied to knowledge work contexts. VSM assists in making intangible work process and tasks more concrete. Many knowledge work jobs tend to be unstructured and broad, requiring task specification while simultaneously presenting other multifaceted 
challenges (Staats \& Upton, 2011; Staats et al., 2011). McDermott and Venditti (2015) have also used work standardization in knowledge work.

Eliminating waste in knowledge work requires adaptation from traditional lean approaches. The lean elements implemented in knowledge work are summarized in Table 5. The more work is standardized and routine-based (i.e. originating from the left side of the knowledge work continuum), the more easily waste is recognized (Kruger, 2014; McDermott \& Venditti, 2015). Rachman and Ratnayake (2016) identify the need to redefine waste categorization to better meet the contextual needs of engineering services. In their case study (engineering service), data management practices can cause major waste; this issue could be tackled by standardizing work (specifically documents) and using a 5S methodology for data management. Such an approach would systematize and simplify data handling practices.

Knowledge work is often realized through extensive collaboration that even highlights the communication practices used throughout projects (Staats \& Upton, 2011). Visual control and tracking are mentioned in some of the cases (such as McDermott and Venditti (2015), Toussaint and Berry (2013), and Staats et al. (2011)), but practical examples of these visualization methods remain unspecified. Instead, they are implied to be white boards with key performance indicators written on them.

The following findings are formulated:

Finding 4. The literature shows examples of implementing lean in knowledge work context. Many of the approaches used tackle the knowledge work definition challenge (see P4) and creating the continuous improvement practices.

Finding 5. Some of the methods are applied only in single case studies, thus the real relevancy of certain lean applications in knowledge work is still arguable and needs more evidence to prove it applicability in knowledge work context. As an example, what is the $5 \mathrm{~S}$ applicability in knowledge work and how this method should adapt in intangible context compare physical manufacturing environment where the method is developed.

\begin{tabular}{|c|c|}
\hline Lean Principles and Methods & Source \\
\hline $\begin{array}{l}\text { Respecting people } \\
\text { Engaging the managers }\end{array}$ & $\begin{array}{l}\text { Toussaint \& Berry (2013) } \\
\text { Staats \& Upton (2011) }\end{array}$ \\
\hline $\begin{array}{l}\text { Value creation } \\
\text { Value Stream Mapping (VSM) } \\
\text { CTQ - Critical To Quality }\end{array}$ & $\begin{array}{l}\text { May (2005); Toussaint \& Berry (2013) } \\
\text { Staats et al. (2011); Toussaint \& Berry (2013); Kruger (2014); McDermott \& } \\
\text { Venditti (2015); Rachman \& Ratnayake (2016) } \\
\text { Kruger (2014) }\end{array}$ \\
\hline $\begin{array}{l}\text { Creating flow } \\
\text { Simplifying process architecture } \\
\text { Kanban } \\
\text { Eliminating waste } \\
\text { Kaizen blitz } \\
5 \text { Whys } \\
\text { PCE - Process Cycle Efficiency } \\
\text { A3 }\end{array}$ & $\begin{array}{l}\text { May (2005); Power \& Conboy (2015) } \\
\text { Staats et al. (2011) } \\
\text { Power \& Conboy (2015) } \\
\text { Staats \& Upton (2011); Kruger (2014); Rachman \& Ratnayake (2016) } \\
\text { McDermott \& Venditti (2015) } \\
\text { Staats \& Upton (2011); Kruger (2014) } \\
\text { Rachman \& Ratnayake (2016) } \\
\text { Toussaint \& Berry (2013) }\end{array}$ \\
\hline $\begin{array}{l}\text { Communication } \\
\text { Visualization: Visual control/ tracking }\end{array}$ & $\begin{array}{l}\text { Staats \& Upton (2011); Staats et al. (2011) } \\
\text { Staats et al. (2011); Toussaint \& Berry (2013); McDermott \& Venditti (2015) }\end{array}$ \\
\hline $\begin{array}{l}\text { Work standardization } \\
\text { (Spaghetti diagrams) } \\
\text { Specify the work } \\
\text { 5S, standard codes and test cases } \\
\text { Lean Six Sigma } \\
\text { Heijunka }\end{array}$ & $\begin{array}{l}\text { Toussaint \& Berry (2013) } \\
\text { McDermott \& Venditti (2015) } \\
\text { Staats \& Upton (2011), Staats et al. (2011) } \\
\text { Staats et al. (2011) } \\
\text { Kruger (2014) } \\
\text { Staats et al. (2011) }\end{array}$ \\
\hline $\begin{array}{l}\text { Continuous improvement (PDCA, DMAIC, } \\
\text { hypothesis-driven problem solving) }\end{array}$ & $\begin{array}{l}\text { May (2005); Staats \& Upton (2011); Staats et al. (2011); Toussaint \& Berry } \\
\text { (2013); Kruger (2014) }\end{array}$ \\
\hline
\end{tabular}

Table 5. Lean elements implemented in knowledge work 


\subsection{Challenges of Identifying Lean in Knowledge Work}

It is necessary to find research that focuses on information and knowledge processing to support value creation. This is challenging because the knowledge work's contexts and practices are rarely well described. The cases at hand seldom describe the complex nature of knowledge work or the different phases of the knowledge process, even though the process' lack of clarity has been identified as a major issue in knowledge work (McDermott \& Venditti, 2015). Task specification (Staats et al., 2011; Staats \& Upton, 2011; McDermott \& Venditti, 2015) is another special challenge when applying lean methods to knowledge work, as it is difficult to specify different tasks and understand their connections. This contrasts Power and Conboy's (2015) request that modern lean thinking, especially in knowledge work, should begin with understanding flow and its obstacles. This often leads to challenges in much knowledge work where workloads are gradually expanded until workers are overwhelmed and handling too much low value activities (Staats \& Upton, 2011). It has also been noted that contextual factors affect the implementation of lean, but only Rachman and Ratnayake (2016) have described what this adaptation might look like in the field of waste identification compared to traditional lean waste in manufacturing.

The extensive literature study of lean services done by Gupta et al. (2016) shows that lean service context is implemented the most in healthcare or IT sectors, but also in the fields of education, finance and even in the public sector. Lean methods in knowledge work are found to be present in engineering, product development, and healthcare (e.g. Staats \& Upton, 2011; McDermott \& Venditti, 2015; Power \& Conboy, 2015; Rachman \& Ratnayake, 2016). Also a few, more philosophical papers examine lean in general in knowledge work context. The cases from the healthcare sector are more challenging because they do not focus on knowledge work as much as they do patient process flow and elimination of waste from a patient's viewpoint (McDermott \& Venditti, 2015). Such studies spend little time focusing on developing knowledge process practices to improve operations.

Finding 6. The lean studies on knowledge work strongly focus on repetitive work where knowledge is a minor resource (e.g. examples in healthcare) rather than the major ingredient of the work output. More research is needed to understand how lean can be implemented in complex knowledge work environment and not only on the other end of the continuum (office work).

\section{Discussion and Implications}

Lean applications in manufacturing have been extensively researched by many scholars. However, we are still in the early stages of investigating lean knowledge work; we do know that a lean approach in knowledge work is built on the same values of respecting people and continuous improvement but that the context of knowledge work should be deeply understood when thinking about detailed lean implementation in knowledge work.

Many researchers, such as McDermott and Venditti (2015), Gupta et al. (2016) and Rahman and Ratnayake (2016), have realized that there are certain needs to adjust traditional lean practices and methods to better tackle various industry-specific characteristics. Knowledge work is often regarded as a unified work and is sometimes made equal to services, but our review demonstrates that knowledge work constitutes different dimensions and is therefore heterogeneous in nature. The presented knowledge work continuum describes the nature of knowledge work. Knowledge work consists of process-related aspects (level of routines, level of formal methods and complexity of tasks), knowledge aspects (use of knowledge, knowledge as an output ingredient, type of knowledge) and people-related aspects (the roles of personal expertise and of collaboration). The key question is to understand: what are we developing with lean methods? In knowledge work, lean methods should place emphasis on how to make the knowledge process more efficient, as well as how to develop the practices of finding, creating, packaging, distributing and applying knowledge. The knowledge work continuum shows that knowledge-intensive work cannot be equated to manufacturing work in which information only serves as operational support.

Finding 7. While the focus of developmental activities in manufacturing are enhancing the productivity of the manufacturing process and the material flow, whereas in knowledge work improvement the focus should lie on developing strong knowledge work practices, the information flow.

Earlier research in the field of lean implementation in knowledge work is scarce, but the knowledge work productivity challenge is not a new phenomenon. Even so, most lean knowledge work-related studies discuss the 
improvement of operations, such as software production or nursing patient processes. Only, a few studies, such as May (2005), Staats et al. (2011) and Rachman and Ratnayake (2016) maintain a different perspective regarding lean applicability in the knowledge work process. Although these academic examples are few, several companies have been taking steps to make their knowledge processes leaner.

As the number of studies about lean knowledge work is sparse, our review can only provide some examples of lean methods applied to knowledge work contexts. The development of the productivity of knowledge work, knowledge-intensive processes, and the adaptation of lean thinking needs to address the challenges of information searching, classification, storage and modification, as well as problem solving. The invisible nature of knowledge work inputs, flows and deliverables must also be addressed. Lean thinking and its tools can contribute to this and help make tacit knowledge work more concrete. VSM, work task specification, and standardization are examples of tools used for that purpose. Focusing on creating flow, recognizing working steps and eliminating waste are also important practices in a knowledge work context. However, in knowledge work, the emphasis is more so placed on adding value than directly targeting waste elimination (May, 2005) and the definitions of value-adding compared to non-value-adding differ from those in the traditional manufacturing industry. In knowledge work, the focus is on practices and methods to handle information (see Rachman \& Ratnayake, 2016), as are the iterations that add value to the final product or service. Even the $5 \mathrm{~S}$ and standardization methods can be implemented in knowledge work, but rather than cleaning the office's physical environment once might find it better to focus on improving knowledge processes to boost productivity. The typical methods of continuous improvement (PDCA/DMAIC) have also been commonly implemented in knowledge work. Individual lean methods such as the 5 Whys, PCE, Heijunka are also applicable, but their general relevance to knowledge work remains open to discussion.

In its current state, the level of productivity development in knowledge work has been poor. In discussions about knowledge work productivity, the role of the worker is often emphasized (e.g. Drucker, 1999b; Ramirez \& Nembhard, 2004) alongside the roles of organizational settings and processes, which can have major impacts on productivity (Ramirez \& Nembhard, 2004; Antikainen \& Lönnqvist, 2006). The lean approach clearly has potential to improve productivity and affect organizational settings and processes. Task definition is among the crucial issues in knowledge work productivity (Drucker, 1999b; Antikainen \& Lönnqvist, 2006), although lean approaches can help clarify task descriptions. Lean practices, such as VSM and standardization, will help in this fundamental issue. Work structure is also required to orient workers to various processes and may be more challenging to complete in different phases of knowledge work, such as in knowledge creation as opposed to knowledge application (Davenport et al., 1996). In knowledge work, the customer focus and task prioritization is often difficult to express. This can be a barrier when implementing lean thinking principles in knowledge work context. The definition of value in knowledge work is not easy to define, and the knowledge work process is often an iterative process with continuous loops, or cycles, of work. Customer pull can also be vague and is sometimes identifiable only after a long period. Waste elimination is one of the most common lean practices applied, according to lean knowledge studies (Staats \& Upton, 2011; Kruger, 2014; Rachman \& Ratnayake, 2016). Although waste is present on knowledge work, waste elimination is not the direct goal_adding value is (May, 2005). The waste in knowledge work is also largely invisible when it is more challenging to tackle. In practice, all knowledge workers know that interruptions, misinformation, or poor collaborative practices may cause waste that can stand to be eliminated. To tackle these types of workplace challenges, lean methods provide many systematic tools to improve such workplace practices. Furthermore, the lean approach provides a set of visualization tools that tackles the intangibility of knowledge work and improves collaboration by implementing critical knowledge in work settings (Staats et al., 2011; Toussaint \& Berry, 2013; McDermott \& Venditti, 2015).

One of the fundamentals of lean is respecting and utilizing people. Surprisingly, lean implementations in knowledge work contexts do not often view knowledge workers as assets although knowledge worker's role in productivity development is obvious. However, research in this area is very limited and lean deployments in knowledge work contexts are missing. Furthermore, lean studies (such as in healthcare or software production) that are often referred to as knowledge work are strongly focused on developing recurring operations with high routine activities, thereby having many similarities with typical manufacturing processes (Bain et al., 2002). Thus, related literature and working practices would surely benefit studies about lean methods in real knowledge-based work 
settings. Good case examples could assist in choosing suitable lean approaches or methods for knowledge-intensive work (represented by the rightmost column in the continuum), as well as improving the knowledge process specifically. More studies are also needed to evaluate which specific lean methods are applicable to knowledge work environments, especially ones involving knowledge-intensive work.

On the practical side, solving knowledge workers' productivity challenges would lead companies a competitive advantage over others due to the increasing excellence of their knowledge operations. Operational excellence in knowledge intensive activities, like strategic management, design, and research could be a way for a company to differentiate itself from competitors.

Finding 8. Improving knowledge work productivity lays on two fundamental issues of utilizing the people better and developing the information flow. Lean approach offers a way to manage both aspects.

\section{Conclusions}

In this research, we studied lean approaches in knowledge work. At first, we examined the definitions of knowledge work and developed a knowledge work continuum to demonstrate the field's multifaceted nature. Our aim was to study how lean is implemented in a real knowledge work context - in other words, in the knowledge process. As per this definition, we conducted a literature study that resulted in only eight papers for final review. The lean methods implemented in these studies were summarized, and focus was given to lean principles and applications to knowledge work. We also identified the challenges of implementing lean knowledge work.

Lean thinking is still strongly influenced by the manufacturing industry, but it is gradually being implemented in new areas like the service industry. The challenges of lean applications in a service context are the overwhelmingly wide variety of services types such as a unified approach to lean methods is hard to develop. It is widely known that successful lean implementation requires an understanding of contextual factors, so to succeed in lean implementation in a knowledge work context, we need to understand both the variation of the knowledge work and what we intend to make lean. When discussing lean in knowledge work, the focus is on the knowledge process and related practices, not recurring operational processes such as patient processes or software production, which are often treated as knowledge work.

We observed that lean has not been studied in the far-right corner of the knowledge work continuum, i.e. in the jobs of researchers and strategic leaders. We have identified this field as the most challenging one with which to integrate lean thinking concepts due to the diversity of tasks and assignments. Lean methods are often applied in operations, which consists of repetitive and definable work that is totally opposite e.g. researchers work. Additionally, the concept of customer or flow can be hard to define in a unified, cohesive way. However, there are still many concepts that can be used in knowledge work such as the value-adding vs. non-value-adding work. Waste, such as interruptions in knowledge workers' informational processing, can also be reduced. When it comes to the digital work life of a knowledge worker, waste comes in the form of emails, chats and phone calls, which can interrupt the knowledge worker's thought process. A lean approach could potentially provide useful methods and practices for maintaining knowledge work productivity, especially organizational settings and processes.

The productivity challenges in knowledge work are widely recognized. In this area, one challenge is to tackle the "fluff" of knowledge work. We have clarified the nature of knowledge work in this study and represented it through a knowledge work continuum that consists of eight dimensions. To better understand the nature of knowledge work, one can initiate instances of lean application. Future research should indicate what type of knowledge work is being studied and what kind developmental methods are usable in certain contexts, since the ways we develop basic office work are different from how we handle knowledge- intensive work.

The limitations of this study include the fact that its literature review only covers journal articles that contain the terms "lean" and "knowledge work". Further studies should examine potential new approaches to lean and knowledge processes or information handling and or try to seek answers from lean case studies (such as ones from consultancies or product development), although the systematicity of the study would then be challenged.

The aim of this study was to understand the lean philosophy's applicability to knowledge work-related settings. The studied literature offers some evidence that different lean methods and practices can be applied, although the 
evidence is not generalized due the small number of studies used. Despite this, we maintain that this study encourages further discussion of lean and its possibilities to improve knowledge work.

To better understand lean approaches in knowledge work, more detailed case studies are required to comprehend how to implement lean in knowledge work, as well as to gauge which practices are especially applicable. We see that topics for further research could also include lean thinking approaches and methodologies to support wellbeing at knowledge work. Many knowledge workers suffer from burn-out, heavy workloads, stress and challenges in the work-life balance; these factors lower the productivity of knowledge workers' main process, the thinking process, which lean approach could improve.

\section{Declaration of Conflicting Interests}

The authors declared no potential conflicts of interest with respect to the research, authorship, and/or publication of this article.

\section{Funding}

The authors received no financial support for the research, authorship, and/or publication of this article.

\section{References}

Aarons, J., Linger, H., \& Burstein, F. (2006). Supporting organisational knowledge work: Integrating thinking and doing in task-based support. In International Conference on Organisational Learning, Knowledge and Capabilities, University of Warwick, $U K$.

Antikainen, R., \& Lönnqvist, A. (2006). Knowledge work productivity assessment. Institute of Industrial Management. Tampere University of Technology. 79-102. Available at: https://www.researchgate.net/publication/228397441 Knowledge work productivity assessment

Bain, P., Watson, A., Mulvey, G., Taylor, P., \& Gall, G. (2002). Taylorism, targets and the pursuit of quantity and quality by call centre management. New Technology, Work and Employment, 17(3), 170-185. https://doi.org/10.1111/1468-005X.00103

Dahooie, H.J., Afrazeh, A., \& Hosseini, S.M.M. (2011). An activity-based framework for quantification of knowledge work. Journal of Knowledge Management, 15(3), 422-444.https://doi.org/10.1108/13673271111137411

Davenport, T.H. (2005). Thinking for a living: how to get better performances and results from knowledge workers. Harvard Business Press, 226.

Davenport, T.H., Jarvenpaa, S.L., \& Beers, M.C. (1996). Improving knowledge work processes. Sloan Management Review, 37(4), 53.

Drucker, P.F. (1969). The age of discontinuity: guidelines to our changing society. Heinemann, 369.

Drucker, P.F. (1999a). Knowledge-Worker Productivity: The Biggest Challenge. California Management Review, 41(2), 79-94. https://doi.org/10.2307/41165987

Drucker, P.F. (1999b). Management Challenges for the 21st Century. Butterworth-Heinemann, 205.

Gupta, S., Sharma, M., \& Sunder, V.M. (2016). Lean services: a systematic review. International Journal of Productivity and Performance Management, 65(8), 1025-1056. https://doi.org/10.1108/IJPPM-02-2015-0032

Hadid, W., \& Afshin Mansouri, S. (2014). The lean-performance relationship in services: a theoretical model. International Journal of Operations \& Production Management, 34(6), 750-785. https://doi.org/10.1108/IJOPM-02-20130080

Hines, P., Holweg, M., \& Rich, N. (2004). Learning to evolve: a review of contemporary lean thinking. International Journal of Operations \& Production Management, 24(10), 994-1011. https://doi.org/10.1108/01443570410558049 
Holtshouse, D. (2010). Knowledge work 2020: thinking ahead about knowledge work. On the Horizon, 18(3), 193-203. https://doi.org/10.1108/10748121011072645

Iivari, J., \& Linger, H. (1999). Knowledge Work as Collaborative Work: A Situated Activity Theory View. In Systems Sciences, 1999. HICSS-32. Proceedings of the 32nd Hawaii International Conference on IEEE. https://doi.org/10.1109/HICSS.1999.772702

Isoherranen, V., Niinikoski, E.-R., Malinen, T., Jokinen, M., Kess, P., \& Karkkainen, M.K. (2016). Operational Excellence Evaluation Model for SME's and Regional Finding. In Industrial Engineering and Engineering Management (IEEM), 2016 IEEE International Conference (199-203). https:/ / doi.org/10.1109/IEEM.2016.7797864

Kobus, J., \& Westner, M. (2015). Lean management of IT organizations: a literature review. PACIS 2015 Proceedings. Available at: http://aisel.aisnet.org/cgi/viewcontent.cgi?article $=1084 \&$ context=pacis2015

Kruger, D.J. (2014). Lean implementation in the Gauteng public health sector. In Management of Engineering and Technology (PICMET), 2014 Portland International Conference on (2699-2708).

Laihonen, H., Jääskeläinen, A., Lönnqvist, A., \& Ruostela, J. (2012). Measuring the productivity impacts of new ways of working. Journal of Facilities Management, 10(2), 102-113. https://doi.org/10.1108/14725961211218749

Liker, J.K. (2004). The Toyota Way. Esensi.

Margaryan, A., Milligan, C., \& Littlejohn, A. (2011). Validation of Davenport's classification structure of knowledge-intensive processes. Journal of Knowledge Management, 15(4), 568-581.

https://doi.org/10.1108/13673271111151965

May, M. (2005). Lean thinking for knowledge work. Quality progress, 38(6), 33-40. Available at: https://www.ksmartin.com/wp-content/files/Lean-Knowledge-Worker.pdf

McDermott, C.M., \& Venditti, F.J. (2015). Implementing lean in knowledge work: Implications from a study of the hospital discharge planning process. Operations Management Research, 8, 118-130. https://doi.org/10.1007/s12063-0150103-7

Newell, S. (2015). Managing knowledge and managing knowledge work: what we know and what the future holds. Journal of Information Technology, 30(1), 1-17. https://doi.org/10.1057/jit.2014.12

Paton, S. (2009). Cutting through the confusion of contemporary work. Journal of Knowledge Management, 13(1), 8897. https://doi.org/10.1108/13673270910931189

Power, K., \& Conboy, K. (2015). A metric-based approach to managing architecture-related impediments in product development flow: an industry case study from Cisco. In Proceedings of the Second International Workshop on Software Architecture and Metrics (15-21). https://doi.org/10.1109/SAM.2015.10

Pyöriä, P. (2005). The concept of knowledge work revisited. Journal of Knowledge Management, 9(3), 116-127. https://doi.org/10.1108/13673270510602818

Rachman, A., \& Ratnayake, R.M. (2016). Implementation of lean knowledge work in oil and gas industry - A case study from a Risk-Based Inspection project. In Industrial Engineering and Engineering Management (IEEM), 2016 IEEE International Conference on (675-680). https://doi.org/10.1109/IEEM.2016.7797961

Ramirez, Y.W., \& Nembhard, D.A. (2004). Measuring knowledge worker productivity: A taxonomy. Journal of intellectual capital, 5(4), 602-628. https://doi.org/10.1108/14691930410567040

Ramirez, Y.W., \& Steudel, H.J. (2008). Measuring knowledge work: the knowledge work quantification framework. Journal of Intellectual Capital, 9(4), 564-584. https://doi.org/10.1108/14691930810913168 
Shah, R., \& Ward, P.T. (2007). Defining and developing measures of lean production. Journal of Operations Management, 25(4), 785-805. https://doi.org/10.1016/j.jom.2007.01.019

Staats, B.R., Brunner, D.J., \& Upton, D.M. (2011). Lean principles, learning, and knowledge work: Evidence from a software services provider. Journal of Operations Management, 29(5), 376-390.

https://doi.org/10.1016/j.jom.2010.11.005

Staats, B.R., \& Upton, D.M. (2011). Lean knowledge work. Harvard Business Review, 89(10), 100-110.

Stone, K.B. (2012). Four decades of lean: a systematic literature review. International Journal of Lean Six Sigma, 3(2), 112-132. https://doi.org/10.1108/20401461211243702

Toussaint, J.S., \& Berry, L.L. (2013). The promise of lean in health care. Mayo Clinic Proceedings, 88(1), 74-82. https://doi.org/10.1016/j.mayocp.2012.07.025

Waters, N.M, \& Beruvides, M.G. (2012). An Empirical Study of Large-Sized Companies With Knowledge Work Teams and Their Impacts on Project Team Performance. Engineering Management Journal, 24(2), 54-62. https://doi.org/10.1080/10429247.2012.11431936

Womack, J.P., Jones, D.T., \& Roos, D. (1990). Machine that changed the world. Simon and Schuster.

Journal of Industrial Engineering and Management, 2018 (www.jiem.org)

\section{(c) (i) (:)}

Article's contents are provided on an Attribution-Non Commercial 4.0 Creative commons International License. Readers are allowed to copy, distribute and communicate article's contents, provided the author's and Journal of Industrial Engineering and Management's names are included. It must not be used for commercial purposes. To see the complete license contents, please visit https://creativecommons.org/licenses/by-nc/4.0/. 